\title{
INTERRELATION OF ECONOMIC GROWTH AND LEVELS OF PUBLIC EXPENDITURE IN THE CONTEXT OF WAGNER'S LAW
}

\author{
Mstislav P. Afanasiev \\ Doctor of Economics, Professor of the Department \\ "Public and Municipal Management", National \\ Research University Higher School of Economics. \\ Address: HSE, 20Myasnitskaya, 101000 Moscow, Russian Federation. \\ E-mail: mstafan@hse.ru
}

\section{Natalia N. Shash}

Doctor of Economics, Professor of Financial Management

Department, Plekhanov Russian University of Economics.

Address: 36 Stremyanny Lane, 117997 Moscow, Russian Federation.

E-mail: nat_vshu@mail.ru

\begin{abstract}
The paper looks into how the law formulated by A. Wagner can be used to stimulate economic growth in a post-crisis period. The major principles of the concept of fiscal economy are given. It is mainly focused on identifying regularities in perpetually growing state spending, which can be explained by increasing the fiscal needs of the state. On the basis of data from 1960 to 2015, this regularity is confirmed for the G7 countries and Russia. It is shown that state spending goes up mostly due to growing pension payments. The authors present the results of Wagner's Law testing obtained by researchers based on the analysis of data on both developed and developing countries. It has been discovered that it is impossible to conclude categorically about a positive effect of fiscal stimulation on economic growth. The main factors which affect the efficiency of the applied fiscal measures are described. Russia is given as an example, where the growth of state spending due to an increase in fiscal needs has not made it possible to ensure the necessary economic growth rate due to its low efficiency. The authors have found out that the main cause of the continually growing budget spending is a large share of the state presence in the Russian economy. This slows down the process of its recovery growth, which does not allow for realizing the existing potential. It has been concluded that state spending efficiency must be improved, among other things, due to a structural transformation of state spending in the budgeting system of the RF.
\end{abstract}

Keywords: Wagner's Law; concept of fiscal economy; economic growth; budgetary policy; budgeting system; state spending; tools stimulating economic growth; fiscal stimulation of the economy; structural efficiency of state spending.

Citation: Afanasiev, M.P. \& Shash, N.N. (2018). Interrelation of Economic Growth and Levels of Public Expenditure in the Context of Wagner's Law. Public Administration Issue, Special Issue II (electronic edition), pp. 174-183 (in English); DOI: 10.17323/1999-5431-2018-0-6-174-183 


\section{Introduction}

The consequences of the financial crisis have not been neutralized so far. They entail threats to the current and future condition of the public sector of the economy and public finances in many countries due to a considerable decrease in public revenues. In the post-crisis period the national governments of quite a few countries (including Russia) have faced a real prospect of further shrinking of budgets. Under the conditions of a slower economic growth rate the outcome is the necessity to additionally reduce state spending. However, a strategy of economic growth based on a sharp reduction of state spending contradicts the global trend of an outstrippingly growing share of public consumption in GDP in comparison to GDP growth (known as Wagner's Law). So, today, most countries all over the world have to solve the problem of defining an optimal volume of state spending, which will help to implement a growth scenario for their national economies.

The need to define the optimal volume of state spending and to increase its efficiency calls for addressing the classical concepts of the theory of public finances anew. In this respect it seems reasonable to analyze in more detail the concept of fiscal economy by A. Wagner and see if it can be applicable in countries which need to stimulate economic growth under the conditions of a growing budget deficit.

\section{The nature of the concept of fiscal economy}

In the concept of A. Wagner's Fiscal Economy, its core is to reveal the regularity of perpetually growing state spending, which is associated with the extensive and intensive increase of the functions of state power in the course of growing state regulation (etatization) of the economy. Wagner established that there is a positive dependence between the level of economic development and the size of the public sector.

This regularity was found as a result of empirical observations in economically developed West European countries and is known as Wagner's Law, which he described in the paper "Nature of the Fiscal Economy". According to the scientist's opinion, the confirmation and reason why fiscal needs grow lie in the social development in a social projection. These arguments about statistical dependency between state spending and the level of economic development are summarized in his "law of increasing state spending" (Wagner, 1958).

According to Wagner's forecast, the tendency for growing state spending, which he witnessed in the $19^{\text {th }}$ century, will continue in developed economies until they keep on developing "continually". These predictions have been repeatedly confirmed by examples of various countries around the world and have proven to be true.

Wagner's Law, in its modern interpretation, says that social development as a whole and industrial growth in particular have to be accompanied by a continually increased share of state spending in gross national product.

Wagner's Law is traditionally checked by the calculation of the share of state spending in GDP, which has been stably growing since the 1830s. Wagner's Law's 
efficiency is confirmed by US data over a period of 100 years (from 1890 to 1990), where the specific weight of state spending in GNP increased from 6 to 33\%, as well as data from the best developed EU countries. Analysis of Wagner's Law testing experience is presented in the paper by B. Dollery, S. Singh (1998).

According to the statistical data, in the early $20^{\text {th }}$ century, developed countries used from $10 \%$ to $30 \%$ of the GDP from their budget to provide public services. In the 1930s (and further on) the volume of state spending grew sharply. This was caused by numerous economic crises and wars. In the period after the Second World War the share of state spending in GDP was going up, mostly due to a fast growth of social expenditures. As a result, by the late $20^{\text {th }}$ century, in most countries all over the world the specific weight of state spending in GDP grew manifold: for example, in the USA, it grew by 4 times (up to $33 \%$ of the GDP), in Germany by 5 times $(45 \%)$.

In the early $21^{\text {st }}$ century, most of the countries in the world witnessed a serious increase in the level of expenditures in \% from the GPD during the period of the latest financial crisis $(2008-2009)$. As a whole in the $20^{\text {th }}-21^{\text {st }}$ centuries, the data of the G7 countries in reference to the expenses of social kind gives evidence in favor of Wagner's Law, especially, in terms of growing assignments into pension benefits (Table).

Table

\section{The share of state spending in the GDP of the G7 countries and Russia in the period 1950-2015, in \%}

\begin{tabular}{|c|c|c|c|c|c|c|c|c|c|}
\hline \multirow{3}{*}{ Year } & \multirow{3}{*}{ total } & \multicolumn{8}{|c|}{ TYPES OF STATE SPENDING } \\
\hline & & \multirow[b]{2}{*}{ governance } & \multirow[b]{2}{*}{ defense } & \multirow{2}{*}{$\begin{array}{l}\text { law } \\
\text { and } \\
\text { order }\end{array}$} & \multicolumn{4}{|c|}{ SOCIAL PROJECTION } & \multirow[b]{2}{*}{ other } \\
\hline & & & & & education & health care & $\begin{array}{c}\text { pensions, } \\
\text { social } \\
\text { benefits }\end{array}$ & total & \\
\hline \multicolumn{10}{|c|}{ USA } \\
\hline 1950 & 24.9 & 0.8 & 13.1 & 0.5 & 3.2 & 0.5 & 3.2 & 7.0 & 3.5 \\
\hline 1980 & 33.5 & 1.5 & 8.5 & 1.3 & 6.6 & 1.5 & 10.1 & 18.2 & 4.0 \\
\hline 1990 & 35.0 & 1.6 & 6.9 & 1.5 & 6.9 & 1.6 & 10.5 & 19.0 & 6.0 \\
\hline 2000 & 35.7 & 1.7 & 4.7 & 1.6 & 7.2 & 1.9 & 10.7 & 20.8 & 6.9 \\
\hline 2015 & 36.5 & 1.0 & 2.6 & 1.4 & 7.7 & 2.3 & 14.6 & 24.6 & 6.9 \\
\hline \multicolumn{10}{|c|}{ FEDERAL REPUBLIC OF GERMANY } \\
\hline 1950 & 28.4 & 1.9 & 4.3 & 1.4 & 2.7 & 3.5 & 12.2 & 18.4 & 2.4 \\
\hline 1980 & 42.4 & 3.2 & 4.4 & 2.4 & 4.8 & 6.8 & 14.0 & 25.6 & 6.8 \\
\hline 1990 & 42.9 & 3.2 & 4.3 & 2.6 & 5.1 & 7.1 & 14.1 & 26.5 & 6.7 \\
\hline 2000 & 42.9 & 3.5 & 4.0 & 2.7 & 5.4 & 7.2 & 14.5 & 27.1 & 5.6 \\
\hline 2015 & 42.8 & 2.6 & 2.5 & 2.5 & 5.7 & 7.5 & 14.5 & 27.7 & 7.5 \\
\hline
\end{tabular}




\begin{tabular}{|c|c|c|c|c|c|c|c|c|c|}
\hline \multirow{3}{*}{ Year } & \multirow{3}{*}{ total } & \multicolumn{8}{|c|}{ TYPES OF STATE SPENDING } \\
\hline & & \multirow[b]{2}{*}{ governance } & \multirow[b]{2}{*}{ defense } & \multirow{2}{*}{$\begin{array}{l}\text { law } \\
\text { and } \\
\text { order }\end{array}$} & \multicolumn{4}{|c|}{ SOCIAL PROJECTION } & \multirow[b]{2}{*}{ other } \\
\hline & & & & & education & health care & $\begin{array}{c}\text { pensions, } \\
\text { social } \\
\text { benefits }\end{array}$ & total & \\
\hline \multicolumn{10}{|c|}{ FRANCE } \\
\hline 1950 & 31.4 & 2.0 & 7.8 & 0.8 & 4.7 & 2.4 & 12.5 & 19.6 & 1.2 \\
\hline 1980 & 45.3 & 2.8 & 5.0 & 1.7 & 8.3 & 4.4 & 19.9 & 32.6 & 3.3 \\
\hline 1990 & 47.2 & 3.5 & 5.7 & 1.3 & 8.7 & 4.8 & 20.0 & 33.5 & 3.3 \\
\hline 2000 & 47.5 & 3.3 & 4.7 & 1.4 & 8.7 & 5.1 & 20.5 & 34.3 & 3.8 \\
\hline 2015 & 45.5 & 2.5 & 3.0 & 1.3 & 8.8 & 5.6 & 20.5 & 34.8 & 3.8 \\
\hline \multicolumn{10}{|c|}{$U K$} \\
\hline 1950 & 32.1 & 1.5 & 4.6 & 1.5 & 5.1 & 5.1 & 7.7 & 17.9 & 6.4 \\
\hline 1980 & 40.6 & 1.9 & 6.9 & 2.5 & 6.9 & 6.9 & 8.8 & 22.5 & 6.9 \\
\hline 1990 & 42.9 & 1.9 & 6.7 & 2.4 & 6.9 & 6.9 & 11.9 & 25.6 & 6.3 \\
\hline 2000 & 43.1 & 2.0 & 5.7 & 2.4 & 7.0 & 7.3 & 12.5 & 26.8 & 6.1 \\
\hline 2015 & 43.4 & 1.7 & 3.5 & 2.3 & 7.2 & 8.1 & 14.5 & 29.8 & 6.1 \\
\hline \multicolumn{10}{|c|}{ ITALY } \\
\hline 1950 & 22.5 & 1.5 & 3.0 & 1.5 & 3.5 & 3.0 & 8.0 & 14.5 & 2.0 \\
\hline 1980 & 38.1 & 2.8 & 3.2 & 2.8 & 6.3 & 5.1 & 13.3 & 24.7 & 4.5 \\
\hline 1990 & 47.9 & 3.7 & 3.7 & 3.2 & 7.4 & 6.5 & 18.0 & 31.8 & 5.5 \\
\hline 2000 & 49.0 & 3.6 & 3.2 & 3.2 & 7.2 & 6.5 & 20.6 & 34.3 & 4.8 \\
\hline 2015 & 45.5 & 2.8 & 2.0 & 2.8 & 6.7 & 6.5 & 19.8 & 33.1 & 4.8 \\
\hline \multicolumn{10}{|c|}{ JAPAN } \\
\hline 1950 & 13.2 & 1.6 & 1.1 & 1.6 & 3.2 & 0.5 & 3.2 & 6.8 & 2.1 \\
\hline 1980 & 25.0 & 1.9 & 1.0 & 1.9 & 5.4 & 0.6 & 10.3 & 16.2 & 3.9 \\
\hline 1990 & 26.9 & 2.1 & 1.0 & 2.1 & 5.6 & 0.7 & 12.0 & 18.4 & 3.4 \\
\hline 2000 & 27.2 & 2.0 & 1.0 & 2.0 & 5.6 & 0.8 & 12.4 & 18.8 & 3.3 \\
\hline 2015 & 29.7 & 1.4 & 0.9 & 2.0 & 5.7 & 1.2 & 14.9 & 21.8 & 3.7 \\
\hline \multicolumn{10}{|c|}{ RUSSIA* } \\
\hline 1950 & 54.4 & 3.4 & 13.6 & 2.7 & 12.9 & 4.8 & 8.2 & 25.9 & 8.8 \\
\hline 1980 & 47.7 & 2.2 & 19.8 & 1.7 & 8.6 & 3.3 & 5.3 & 17.2 & 6.8 \\
\hline 1990 & 52.2 & 2.3 & 21.7 & 2.0 & 9.9 & 2.9 & 6.1 & 18.8 & 7.2 \\
\hline 2000 & 42.4 & 2.8 & 9.2 & 2.3 & 10.6 & 3.2 & 6.5 & 20.3 & 7.8 \\
\hline 2015 & 43.3 & 3.1 & 7.8 & 2.7 & 11.8 & 4.0 & 6.7 & 22.4 & 7.3 \\
\hline
\end{tabular}

Source: www.rosbalt.ru

* USSR / Russian Federation 
When the data presented in Table 1 is analyzed and the RF is compared to the G7 countries by the level of expenditures in relation to GDP, it should be considered that it is comparable with these countries in terms of the demographic processes and volume of social commitment. However, it falls behind them by the size of GDP per capita and is not that advanced by the level of economic efficiency, labor productivity, and the quality of state finance. Thus, in terms of sustainability and harmony of the budget system, Russia, objectively, cannot have the same volume of state spending in relation to GDP as in the economically developed countries. These are the factors which explain that in the Russian Federation the general volume of state spending on education is within the limits of $4.0-4.5 \%$ of GDP, on health care $-3.5 \%$ of GDP, while the average values in the developed countries are $5.3 \%$ and $6.6 \%$ correspondingly.

There are three main reasons why state spending continually grows (Fig.).

\section{Main causes of growth in state spending}

$\begin{array}{ll}\text { CAUSES } & \text { EFFETS } \\ \text { SOCIO- } & \begin{array}{l}\text { Over the last few decades the state social functions have } \\ \text { bOLITICAL } \\ \text { care and other "social" services pertain to elastic functions) }\end{array} \\ \text { ECONOMIC } & \begin{array}{l}\text { Due to science and technology advances, state assignments } \\ \text { into fundamental research, infrastructure and investment } \\ \text { projects increase and the demand for them grows faster } \\ \text { than public revenues }\end{array} \\ \text { HISTORICAL } & \begin{array}{l}\text { In order to cover contingencies, the state emit government } \\ \text { loans, which may cause the amount of state spending and } \\ \text { interest grow }\end{array}\end{array}$

Composed by the authors

The research studies by H. Timm (1961) are of interest. They prove that there is a consistency in outstripping growth of state spending (in comparison to private spending) and it is established that fiscal needs form in a more inertial way, due to a complex procedure for approval of the state budget through parliament.

\section{Interpretation of Wagner's Law and the Search for Balance between State Spending and National Income}

Wagner's Law is quite regularly tested by finance researchers who use various econometric models on an abundant country material (Afanasiev M. \& Afanasiev Ya., 2009). However, a detailed analysis provides for less consistent results, because the main principles of this law have allowed for proposing various variants and methods for its testing, related to two quite clearly distinctive subgroups of the original argumentation.

The first interpretation of Wagner's Law says that the appearance of industrialized societies is accompanied by a bigger volume of social benefits and services provided by the state, such as, for example, education, health care or so- 
cial insurance, which increases the number of state functions and stimulates the growth of state spending (Dollery \& Singh, 1998).

This version of Wagner's Law, referring to restructuring societies, has not been proven, on the basis of the analyzed empirical data as well as the second version of the law. Some researchers, such as E. Hook (1962), A.J. Mann (1980), F. Gould (1983), R. Neck and F. Schneider (1988), M. Paldam and H.E. Zeuthen (1988), M. Yousefi and S. Abizadeh (1992), as well as F. Hackl, F. Schneider and G. Withers (1993), proved Wagner's Law when they analyzed the empirical data of the developed countries and their groups in various time intervals. Others, for instance, J.E. Pluta (1981), D. Lowery and W.D. Berry (1983), J.A. Lybeck (1986), R. Ram (1986), G. Hondroyiannis and E. Papapetrou (1995), F. Halicioglu (2003), did not find grounds for confirmation of Wagner's Law in terms of increasing state spending in restructuring economies.

In the course of the research studies two main problems were identified about this version of Wagner's Law. The first one: the phenomenon of outstripping growth in state spending in relation to the growth rate of GDP is mostly witnessed after 1945 (Dutt \& Ghosh, 1997; Goffman, 1968). The second one: A. Wagner's statement that the state starts providing goods and services which can no longer be provided by private companies is not explained or proven empirically (Biehl, 1998; Engle \& Granger, 1987).

The second interpretation of Wagner's Law is grounded on the nature of such social goods and services as education, health care and infrastructure. The law says that, as a whole, such goods and services refer to elastic demand. Moreover, the demand for these goods and services will be growing faster than the national income, since, when the state revenues grow, so does the consumption of public goods and services, in compliance with the population's expectations concerning the increase in the resources used for production of social goods (in comparison to private ones).

As for the second version of Wagner's Law, as a whole, most researches prove that it is true on the basis of analyzed empirical data. Only a few researchers do not find empiric grounds for this version of Wagner's Law.

Although empirical research in relation to Wagner's Law is not categorical, many countries, and according to Wagner's Law, widely use the measures of fiscal stimulation to support their economies in crisis periods. At the same time, the available results of research studies about how fiscal stimulation affects economic growth do not allow one to define categorically the nature of such influence. When one evaluates the feasibility of fiscal tooling use for stimulation of the Russian economy, one should not forget about a danger of a wrong evaluation.

This instrument, if used in times of recessions, can bring about erroneous conclusions referring to the time of early economic growth and the size of required financing for realizing a set of fiscal measures, which challenges the efficiency of this tooling.

Moreover, most countries cannot virtually increase the tax rates or the size of public debt to finance the growing budget expenditures. So, in order to ensure the required economic growth rate, reforms should be initiated, which are aimed at restricting the growth of state spending with simultaneous increase in its efficiency. 


\section{"Structural" Efficiency of the Russian Federation's}

\section{Budget System Expenditures}

The efficiency of state spending as a tool for growth stimulation, apart from structural and time factors, also depends on how it will be used. Thus, for example, one should note the paper by E.C. Wang, E. Alvi (2011), where the data is given referring to the relative efficiency analysis of state spending and factors affecting it are revealed. The research study by Rahmayanti Y., Horn Th. (2010) seems interesting too. It is dedicated to the influence of state spending on economic growth and proves, based on the analysis of macroeconomic indicators in 63 developing countries (throughout 1990-2004), that there is a certain critical level of efficiency of state spending when it exerts the maximally positive impact on the rate of economic growth. The results of the research show that if the efficiency of state spending is lower or higher than this level, the state does not use the budget funds optimally, which, in turn, brings about losses of potential capabilities for economic growth.

The data on the efficiency evaluation results of the state action in the economy shows that the expenses related to maintenance of the state sector are growing and its efficiency is reducing. For example, over the last 15 years in the Russian Federation the total volume of expenses of the budget system has grown from $34.3 \%$ to $40.8 \%$ of GDP, and there is no visible improvement by the majority of indicators, which characterize the results of the state policy. Thus, over several latest budget cycles, social expenditure has grown considerably. For instance, if in the year 2000 retirement expenditure and social benefits accounted for $7.3 \%$ of GDP $(21 \%$ of expenditure of the budget system), then in the year 2015 this indicator reached $12.3 \%$ of GDP (32\% of expenditure of the budget system). At the same time the efficiency of expenditure of the RF budget system on social policy remains low, since despite perpetually growing state spending, the poverty level of Russians is reducing very slowly. The audit of budget expenditure efficiency in the period 2013-2015 showed that among Russians who get social benefits more than $50 \%$ do not belong to the category which needs this aid. At the same time, less than 50\% of the citizens who need social support get benefits. Thus, the more budget assignments are sent to the social support system, the greater is social inequality and the lower is the efficiency of expenditure in this area.

There are other similar examples of functional inefficiency of expenditure, which together confirm that there is a system limitation related to the quality of state administration in Russia.

According to the international experience, in the middle-term period, fiscal consolidation stimulates sustainable economic growth due to more efficient distribution of all sorts of resources, lower uncertainty and reduced real interest rates. These conclusions are true for quite a number of economies with a developed raw material sector, comparable to Russia, like, for example, Mexico, Malaysia or Chile.

At the start of 2015 the Russian government, through one-time correction of the currency exchange rate and the level of prices, initiated a mechanism for the economy to adapt to macroeconomic shocks. Consequently, the effect of monetary policy on inflation dynamics began to reduce. However, the indexation of 
the main social benefits (pensions, allowances, salaries in the budget sector of the economy) by consumer price index (actual or projected inflation rate), which has been conducted according to the requirements of the Russian legislation, results in the neutralization of the adaptation mechanism and may unwind the inflation spiral. At the same time, the major cause of the continual growth of budget expenditure is the large share of the state in the Russian economy. It slows down its recovery growth and does not allow for realizing the available potential.

Hence for the year 2017, the target share of consolidated budget expenditure in GDP was set as 35\%, which is 3\% lower in comparison to the year 2014 ( $38.1 \%$ of GDP). This value is close to optimal ( $33 \%$ of GDP), defined subsequent to the results of variants calculations of real economic growth rate dependence on the share of state spending in GDP. According to this, the main objective in the current budget cycle (years 2018-2020) should be the limitation of budget expenditure growth rates, including expenses for social projects. The share of state spending in GDP is expected to diminish, primarily, due to a reduction of inefficient spending.

However, the optimization measures aimed at balancing the federal budget with the current amount of social obligations and the position about security and defense expenses can end up in a situation when, under the structure of state budget expenditure in the period 2018-2020, this inertia may become stronger and thus, recovery capabilities of the budgetary policy will be even more hindered. According to the results of long-term economic growth simulation, the share of budget expenditure in GDP is inversely proportional to the rate of potential economic growth.

The situation is also aggravated by the fact that the share of unproductive expenses, i.e. social policy expenditure (including retirement system expenses) and expenses for the state machine maintenance (including defense and security) have grown between 2008 and 2018 from 49\% to 59\%. This change in the structure of expenses contradicts with the solution to the problem of economic growth activation. In the expenditure structure of the budget system, by sections of functional classification in the year 2017, the major share of expenses still includes expenses for social policy (13.5\% of GDP), national defense (3.3\% of GDP), national economy (4.4 of GDP), education (3.6\% of GDP), national security and law enforcement (2.4\% of GDP). Moreover, according to the authors' forecast, the share of expenses for defense, security, social policy and public debt interest in the year 2019 could reach $72 \%$.

In today's conditions some principle aspects, on which the "structural" efficiency of budget system expenditure depends, must be identified.

Firstly, an optimal size of defense expenses should be defined. The share of defense expenses in the RF is higher than the average level in OECD and BRICS countries - more than $4 \%$ of GDP in comparison to the values of about $1-2 \%$ of GDP for both groups of countries.

Secondly, the existing budget resources should be distributed in a balanced way between the current (as a rule, social) expenses and expenses for development (in a broad sense - infrastructure, education, health care and support of innovations). 


\section{REFERENCES}

1. Afanasiev, M.P. \& Afanasiev Ya.M. (2009). Methodological and Theoretical Bases of the Formulation of the A. Wagner's Law. Approaches to Testing. Public Administration Issues, no 3, pp. $47-70$.

2. Biehl, D. (1998). Wagner's Law: An Introduction to and A Translation of the Last Version of Adolph Wagner's Text of 1911. Public Finance/Finances Publiques, vol. 53, no 1, pp. 102-111.

3. Bird, R.M. (1971). Wagner's law of expanding state activity. Public Finance, vol. 26, no 1, pp. 1-26.

4. Dollery, B. \& Singh, S. (1998). A Note on the empirical analysis of Wagner's law. Economic Analysis \& Policy, vol. 28, no 2, pp. 245-257.

5. Dutt, S.D. \& Ghosh, D. (1997). An Empirical Examination of the Public Expenditure Economic Growth Correlations. Southwest Oklahoma Economic Review, vol. 12, no 4, pp. 14-26.

6. Engle, R.F. \& Granger, C.W.J. (1987). Co-Integration and Error Correction: Representation, Estimation, and Testing. Econometrica, vol. 55, no 2, pp. 251-276.

7. Goffman, I.J. (1968). On the Empirical Testing of Wagner's Law: A Technical Note. Public Finance, vol. 23, no 3, pp. 359-364.

8. Gould, F. (1983). The Development of Public Expenditures in Western Industrialized Countries: A Comparative Analysis. Public Finance, vol. 38, no 1, pp. 38-69.

9. Hackl, F., Schneider, F. \& Withers, G. (1993). The public sector in Australia: A quantitative analysis. In: N. Gemmell (Ed.). The Growth of the Public Sector. Edward Elgar, Aldershot, UK, pp. 212-231.

10. Halicioglu, F. (2003). Testing Wagner's Law for Turkey. 1960-2000. Review of Middle East Economics and Finance, vol. 1, no 2, pp. 129-140.

11. Hondroyiannis, G. \& Papapetrou, E. (1995). An Examination of Wagner's Law for Greece: A Co-integration Analysis. Public Finance, vol. 50, no 1, pp. 67-79.

12. Hook, E. (1962). The Expansion of the Public Sector: A Study of Development of Public Expenditures in Sweden during the Years 1912-1958. Public Finance, no 17, pp. 289-312.

13. Lowery, D. \& Berry, W.D. (1983). The Growth of Government in the United States: An Empirical Assessment of Competing Explanations. American Journal of Political Science, no 27, pp. 665-694.

14. Lybeck, J.A. (1986). The Growth of Government in Developed Countries. London: Gower.

15. Mandl, U., Dierx, A. \& Ilzkovitz, F. (2008). The Effectiveness and Efficiency of Public Spending. Economic Paper, no 301, (Feb.), European Communities.

16. Mann, A.J. (1980). Wagner's Law: An Econometric Test for Mexico, 1925-76. National Tax Journal, vol. 33, no 2, pp. 189-201.

17. Neck, R. \& Schneider, F. (1988). The growth of public expenditure in Austria: an exploratory analysis. In: J.A. Lybeck (ed.). Explaining the Growth of Government. North-Holland (Amsterdam).

18. Paldam, M. \& Zeuthen, H.E. (1988). The expansion of the public sector in Denmark a post festum. In: J.A. Lybeck (ed.). Explaining the Growth of Government. North Holland (Amsterdam). 
19. Pluta, J.E. (1981). Real public sector growth in decline in developing countries. Public Finance, no 36, pp. 39-54.

20. Rahmayanti, Y. \& Horn, Th. (2010). Expenditure Efficiency and the Optimal Size of Government in Developing Countries. Discussion Paper, pp. 10-20.

21. Ram, R. (1986). Causality between Income and Government Expenditure: A Broad International Perspective. Public Finance, vol. 41, no 3, pp. 393-414.

22. Timm, H. (1961). Das Gesetz Des Wachsenden Staatsausgaben. Finanzarchiv, Vol. 19, P. 201-247.

23. Wagner, A. (1958). Three Extracts on Public Finance (Nature of the Fiscal Economy). In: Classics in the Theory of Public Finance. Eds. by Musgrave R.A. and Peacock A.R. London: Macmillan, pp. 1-15.

24. Wang, E.C. \& Alvi, E. (2011). Relative Efficiency of Government Spending and its Determinants: Evidence from OECD and Asian Countries. Eurasian Economic Review, June, vol. 1, no 1, pp. 3-28.

25. Yousefi, M. \& Abizadeh, S. (1992). Growth of State Government Expenditures: Empirical Evidence from the United States. Public Finance, no 47, pp. 322-339. 